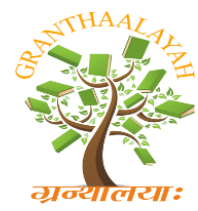

INTERNATIONAL JOURNAL OF RESEARCH GRANTHAALAYAH

A knowledge Repository

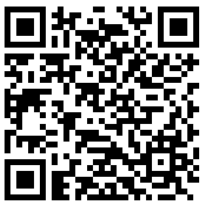

Social

\title{
JUDICIAL REVIEW: A STUDY IN REFERENCE TO CONTEMPORARY JUDICIAL SYSTEM IN INDIA
}

\author{
Dr. Rahul Tripathi ${ }^{* 1}$ \\ ${ }^{* 1}$ Assistant Professor, Amity University, Jaipur (Rajasthan), INDIA
}

\begin{abstract}
Judicial review is the process by which the Courts determine whether or not an administrative decision-maker has acted within the power conferred upon him or her by Parliament. That places the question of statutory construction at the heart of the enquiry. The Supreme Court enjoys a position which entrusts it with the power of reviewing the legislative enactments both of Parliament and the State Legislatures. This grants the court a powerful instrument of judicial review under the constitution. Research reveals that the Supreme Court has taken in hand the task of rewriting the Constitution, which is an important aspect in present scenario.
\end{abstract}

Keywords:

Judicial Review, Activism, Writ, Article.

Cite This Article: Dr. Rahul Tripathi, "JUDICIAL REVIEW: A STUDY IN REFERENCE TO CONTEMPORARY JUDICIAL SYSTEM IN INDIA" International Journal of Research Granthaalayah, Vol. 4, No. 5 (2016): 51-55.

\section{INTRODUCTION}

"EQUAL JUSTICE UNDER LAW"-These words reflect the ultimate responsibility of the Judiciary of India. In India, the Supreme Court is the highest tribunal in the Nation for all cases and controversies arising under the Constitution or the laws. As the final arbiter of the law, the Court is charged with ensuring the of Indian people the promise of equal justice under law and, Judicial Review and Judicial Activism: Administrative Perspective \& Writs.

Judicial review is the process by which the Courts determine whether or not an administrative decision-maker has acted within the power conferred upon him or her by Parliament. That places the question of statutory construction at the heart of the enquiry. The question that Courts are called upon to answer is whether or not the provision or provisions of a statute under which the decision-maker acted empowered them (that is, gave them jurisdiction) to make the decision which they did, for the reasons which they did, following the procedure which they did. In other words, the heart of the enquiry when engaging in judicial review is the interpretation of the statute to determine what the decision-maker is entitled to do, and what the decision maker must do. ${ }^{1}$ 
The inverse of that proposition is that the categories of jurisdictional error simply represent the ways in which a decision-maker can go outside the power conferred upon them by the statute, or fail to do what the statute requires them to do.

\section{CONSTITUTIONAL PROVISIONS FOR JUDICIAL REVIEW}

The Indian Constitution adopted the Judicial Review on lines of U.S. Constitution. Parliament is not supreme under the Constitution of India. Its powers are limited in a manner that the power is divided between centre and states.

Moreover the Supreme Court enjoys a position which entrusts it with the power of reviewing the legislative enactments both of Parliament and the State Legislatures. This grants the court a powerful instrument of judicial review under the constitution.

Both the political theory and text of the Constitution has granted the judiciary the power of judicial review of legislation. The Constitutional Provisions which guarantee judicial review of legislation are Articles 13, 32, 131-136, 143, 226, 145, 246, 251, 254 and 372.

Article 372 (1) establishes the judicial review of the pre-constitution legislation.

Article 13 declares that any law which contravenes any of the provisions of the part of Fundamental Rights shall be void.

Articles 32 and 226 entrusts the roles of the protector and guarantor of fundamental rights to the Supreme and High Courts.

Article 251 and 254 states that in case of inconsistency between union and state laws, the state law shall be void.

Article 246 (3) ensures the state legislature's exclusive powers on matters pertaining to the State List.

\section{FEATURES}

In order to avoid the controversy as to the rationale of the doctrine of judicial review and the consequential academic turmoil on the same, it would be wise to see the power of judicial review, not as 'judicial control' of administration and legislation but as 'judicial protection' of individual against abuse of power. The possibility of a judicial challenge against perversity in exercise of public power may dissuade the administrator as well as legislator from stepping out of the constitutional guidelines and the common law principles.

Judicial review has laid down its solid foundation on the reasoning that it is the constitution, constitutionalism and rule of law that are being protected by the judiciary; and that it is not the institutional supremacy of the judiciary, rather it is that of the constitution that is being defended by judicial review. All the arguments for and against the doctrine have not yet settled the issue, which continues to occupy the centre stage of debates on public law. ${ }^{3}$ However, the fact remains 
that public power should carry with it some check and balance to ensure that they are not exceeded or abused. The concept of constitutional government and limited government, maintained through the mechanism of judicial review, balance the conflict between the judiciary, the executive and the legislature. As the Constitution is organic, it demands creative and meaningful interpretation suiting the needs of the changing times. Despite the valid criticism against the undue expansion of the limits of judicial review, the fact remains that, it acts as a safety valve on moments of crisis created by conflicting interests in the society, so as to ease societal tension and to avoid civic conflicts. It functions as a shock absorber to absorb the illegalities and irregularities without the impact being suffered by the society. It is for the judiciary to ensure that the interpretations that they give are in public interest and for public good. If there is any judicial onslaught on the constitutional equilibrium, it should be defended by informed public opinion capable of appraising and criticizing the consequences and constitutional implications of such judgments.

\section{POWER TO REVIEW}

Like the American Supreme Court, the Supreme Court of India enjoys the power of judicial review and this power has been specifically recognised by the constitution.

Though the courts have the power of judicial review, the same cannot be exercised in an arbitrary fashion. If the law-making power of parliament is not unlimited, the courts power to review the laws passed by parliament is also not unlimited. Like other organs of the state, the judiciary derives its powers from the constitution and the judges are as much under the constitution as anyone else. They can interpret and invalidate laws but they cannot themselves assume the law making function; nor can they confer that function on any person or institution other than the federal or provincial legislatures. Nor can the courts make constitutional what is manifestly unconstitutional. Sovereignty is located neither in parliament nor in the judiciary.

The absence of any legislative interference with judicial functions in a manner characterized by Dean Roscoe Pound as "legislative lynching" or threats of any kind held out for particular conclusions however unpalatable they may be to anyone ${ }^{4}$

"The Constitution is either superior paramount law unchangeable by ordinary means or it is on a level with ordinary legislative acts, and like other acts are alterable when the legislature shall please to alter it. Certainly all those who framed written Constitution contemplate them as forming the fundamental and paramount law of the nation and, consequently the theory of every such government must be that an Act of legislature repugnant to the Constitution is void. And, further, it is emphatically the province and duty of the judicial department to say what law is."

Researches have shown that the U.S. Supreme Court, which innovated the doctrine of judicial review in Marbury v. Madison ${ }^{6}$, has also restrained itself from declaring the constitutional amendments as unconstitutional, on the ground of implied and inherent limitations. However, the Supreme Court of India has gone to the extent of applying the doctrine to the constitutional Amendment though amendment is essentially a policy matter, which a Parliament alone is competent to decide. Again, the amendment is essentially a political question, which cannot be the subject matter of value judgment by the Court. ${ }^{7}$ Perhaps India is a unique democratic set-up 
where Court has blocked the Parliament from amending the certain essential provisions of the Constitution unknown to the parliament. ${ }^{8}$ Rajeev Dhavan has rightly points out that Keshavananda had pushed judges into open politics. ${ }^{9}$ Prof. P. K. Tripathi has gone to the extent of asking the Court; "Will it also contest election?"10

The categories of jurisdictional error are simply ways of describing what a decision-maker has done when they have gone beyond the power conferred upon them by the statute, or when they have failed to exercise a power conferred upon them by the statute. The categories of error are not closed because there could always be another way of describing what a statute requires or forbids and how that obligation or restriction has not been complied with.

\section{ROLE OF SUPREME COURT}

It can be concluded that it is Parliament's attempts to restrict access to the Courts in particular (and Parliament's efforts to confine the content of procedural fairness to a lesser extent) which has led to the flourishing of a system of judicial review which is more flexible, more robust, and more extensive than ever before.

Research reveals that the Supreme Court has taken in hand the task of rewriting the Constitution, which is certainly not within its domain. It has tried to read what has not been written in it. By doing so it has defeated the intention of the founding fathers. The judges take their oaths to defend the Constitution, not as originally enacted but as it are in force having been amended from time to time ${ }^{11}$. No Court should, therefore, have power to declare a provision of the Constitution as unconstitutional and in fact, in no countiy of the world, Courts have power to strike down a constitutional amendment. Prof. Tope has rightly said that the theory of basic structure is nothing but judicial legislation. ${ }^{12}$ Constitution should not be used to defeat the Constitution

"The incorporation of void and illegal Acts into the Constitution make them constitutional is a striking proof of the failure of Indian legislation to conform to the Constitution under which it works." ${ }^{, 13}$ The power of judicial review is exercised by judges on behalf of the people of India. Justice Krishna Iyer has aptly remarked that- "The judicial power is exercised by courts on behalf of the people of India, as long as "WE THE PEOPLE" have appointed them to exercise such power." 13

\section{CONCLUSION}

The concept of judicial review of administrative action is inherent in our Constitutional scheme which is based on rule of law and separation of powers. It is considered to be the basic features of our Constitution, which cannot be abrogated even by exercising the Constituent power of parliament. It is the most effective remedy available against the administrative excesses. Well it is positive sense among the masses that if the administration undertakes any work or acting under discretion power conferred upon it either by statutory rules or under the provisions of the Constitution of India. If it is failure to exercise discretion or abuse of discretion power to settle its score or gain any private profit due to this discretion power, then only option before the public is to go to judiciary under Article 32,136 or Article 226 of the Constitution of India. ${ }^{14}$ The 
main purpose of judicial review is to ensure that the laws enacted by the legislature conform to the rule of law. Judicial review has certain inherent limitations. It is more suited for adjudication of disputes than for performing administrative functions. It is for the executive to administer the law and function of judiciary is to ensure that government carries out its duty in accordance with the provision of the Constitution of India. ${ }^{15}$

\section{REFERENCES}

[1] D. D. Basu, "Limited Government and Judicial review', p. 69

[2] Mirza H. Beg, "The Supremacy ofthe Constitution”, In Indian Constitution: Trends and issues, edited by Rajeev Dhavan and Alice Jacob, p. 121, N. M. Tripathi, Bombay, 1978

[3] Mirza H. Beg, "The Supremacy ofthe Constitution”, In Indian Constitution: Trends and issues, edited by Rajeev Dhavan and Alice Jacob, p. 121, N. M. Tripathi, Bombay, 1978

[4] (1803) Cranch 137, 2 L Ed. 60

[5] (1803) 1 Cranch 137; 2 L. Ed. 60 M. K. Bhandari, "Basic Structure ofthe Indian Constitution", p. 353, Deep and Deep Publication, 1993705 Anirudhh Prasad, "Democracy, Politics and Judiciary in India" p. 1311983

[6] Rajeev Dhavan "The Basic Structure Doctrine-A Footnote Comment" in Indian Constitution-Trends and Issues p. 178

[7] Rajeev Dhavan "The Basic Structure Doctrine-A Footnote Comment" in Indian Constitution-Trends and Issues p. 178

[8] Rajeev Dhavan "The Basic Structure Doctrine-A Footnote Comment" in Indian Constitution-Trends and Issues p. 178

[9] P. K. Tripathi, "Rule of Law, Democracy and frontiers of Judicial Activism” p. 36, JILI; 1975

[10] R. C. S. Sarkar, “Judicial Review”, in the framework ofIndian Politics, p. 112, 1983

[11] T. K. Tope, "Constitutional law ofIndia”, p. 440, 1982

[12] Vide, Justice Mukheijee, "Role ofthe judiciary in governmental process" in Patna Law College Journal, 1967, Vol. XLII, p. 41

[13] Vide, V. R. Krishna Iyer, "Law and the people", 1972 at p. 163

[14] Ram Javaya v. State of Punjab, AIR 1955 SC 549

[15] Dr. Hari Chand: "The implied limitations Theory-A Critique", Journal ofthe Bar Council ofIndia, Vol. 4 (1-4) 1975 